\title{
OCCURENCE OF THRIPS ON NIAGARA TABLE GRAPE AND ITS CONTROL WITH THE INSECTICIDES THIACLOPRID AND METHIOCARB ASSOCIATED WITH METARHIZIUM ANISOPLIAE ${ }^{1}$
}

\author{
ROGÉRIO BIAGGIONI LOPES², MARCO ANTONIO TAMAI², SÉRGIO BATISTA ALVES², \\ SINVAL SILVEIRA NETO², SÉRGIO DE SALVO ${ }^{3}$
}

\begin{abstract}
Thrips are reported as important pests on table grapes in United States and several countries of Europe. Damage caused by thrips, particulary Frankliniella occidentalis, was observed on niagara table grape crop in Limeira-SP, Brazil. During the blooming period, high thrips densities were observed feeding on pollen and small berries. The symptoms left were more visible after the development of the berries and were characterized by dark scars and suberized surface on berries, sometimes causing the berry to crack, and the seed to prolapse. The effect of insecticides thiacloprid or methiocarb, associated or not with the entomopathogenic fungus Metarhizium anisopliae were evaluated during the blooming period. For evaluation of thrips damage on fruits, the treatments were applied three additional times, 7, 14 and 21 days after the first application. The treatments were: a) M. anisopliae (strain 1037) $1 \times 10^{7}$ conidia/mL; b) thiacloprid $20 \mathrm{~mL} / 100 \mathrm{~L}$; c-d) methiocarb 100 and $150 \mathrm{~mL} / 100 \mathrm{~L} ; \mathrm{e}$ ) methiocarb $100 \mathrm{~mL} / 100 \mathrm{~L}+$ M. anisopliae $1 \times 10^{7}$ conidia/ $\mathrm{mL}$. Only methiocarb, associated or not with the fungus, was effective in reducing thrips infestation, and no phytotoxic damage was observed. The efficiency of methiocarb $150 \mathrm{~mL} / 100 \mathrm{~L}$ and the insecticide associated with the fungus for the control of the thrips population was 84.2 and $95.5 \%$, respectively. In both cases, there was a reduction of approximately $70 \%$ in the number of berries with scars symptoms. For control of thrips on table grapes, chemical insecticides associated or not with M. anisopliae should be applied during the blooming period of the crop.
\end{abstract}

Index terms: chemical control, fungi, microbial control, thrips.

\section{OCORRÊNCIA DE TRIPES EM UVA NIAGARA E SEU CONTROLE COM OS INSETICIDAS THIACLOPRID E METHIOCARB ASSOCIADOS COM METARHIZIUM ANISOPLIAE}

RESUMO - Os tripes são mencionados como importantes pragas da cultura da uva de mesa em diversos países da Europa e Estados Unidos. Em área de cultivo da uva Niagara localizada na região de Limeira-SP verificou-se a ocorrência de danos provocados por Frankliniella occidentalis. Essa praga foi observada, principalmente, durante a fase de florescimento, alimentando-se de pólen e bagas em início de formação. Os sintomas do ataque são mais visíveis com o desenvolvimento dos frutos e caracterizam-se por cicatrizes escuras e suberizadas nas bagas, provocando em alguns casos a rachadura das mesmas com prolapso das sementes. Avaliou-se o efeito de uma única aplicação dos inseticidas Calypso 480SC (thiacloprid) e Mesurol (methiocarb) associados ou não ao fungo entomopatogênico Metarhizium anisopliae, sobre a população da praga durante o período de florescimento. Para a avaliação do dano nos frutos foram realizadas mais três aplicações 7, 14 e 21 dias após a primeira. Os tratamentos foram: a) M. anisopliae (isolado 1037) $1 \times 10^{7}$ conídios $/ \mathrm{ml}$; b) Calypso 20ml/100L; c-d) Mesurol 100 e 150ml/100 L; e) Mesurol 100ml/100L + M. anisopliae 1x10 conídios/ $\mathrm{ml}$. Apenas o produto Mesurol associado ou não ao entomopatógeno apresentou efeito de controle sobre a praga, não sendo observados danos fitotóxicos. Nos tratamentos Mesurol 150ml/100L e do produto associado com o fungo a eficiência de controle da população do tripes foi de 84,2 e $95,5 \%$, respectivamente, nos dois casos com redução de aproximadamente $70 \%$ no número de bagas com sintomas de ataque da praga. Para o controle de tripes em uva as aplicações de inseticidas químicos combinados ou não com $M$. anisopliae devem ser realizadas na época de florescimento da cultura.

Termos para indexação: controle químico, controle microbiológico, tripes

Thrips are mentioned as pests on table grapes in important areas of Italy, USA, Chile and Mexico. Many species of thrips have been reported causing damages on grapes, such as Dreapanothrips reuteri (Uzeli), Thrips tabaci (Lindemam), Frankliniella cestrum Moulton and F. occidentalis (Pergande)
(McNally et al., 1985; War-Sobrevilla, 1989; Ripa et al., 1993; Moleas \& Addante, 1995). Fruit damage results from the feeding and oviposition of the insect during the blooming period and early post-blooming stages, affecting the quality and commercialization of the product (Yokoyama, 1979; McNally et

1 (Trabalho 064/2001). Recebido: 13/03/2001. Aceito para publicação: 22/02/2002.

2 Dept. Entomologia, Fitopatologia e Zoologia Agrícola, ESALQ/USP, Pádua Dias Ave., 11, C. Postal 9, Piracicaba, SP, 13418-900, Brazil, E-mail rblopes@carpa.ciagri.usp.br;

3 Bayer S.A., Domingos Jorge St., 1100, São Paulo, SP, 04779-900, Brazil. 
al., 1985).

In Brazil, there are no reports of thrips as pests of grapes. However, since 1996, thrips have been observed on "Niagara" table grape crops in Limeira-SP, with high populations occurring during the blooming period, feeding on pollen and small berries. The present research was carried out to describe the damage caused by F. occidentalis on grape and to evaluate the efficacy of the insecticides thiacloprid and methiocarb associated with the fungus Metarhizium anisopliae for the control of the insect.

Thrips damage on "Niagara" table grape: Samples of the insects were collected from vineyards of "Niagara" table grape in Limeira-SP for species identification, between September and October of 1999. The samples were collected during the blooming period with a thin brush and placed in AGA liquid (Palmer et al., 1989) for identification. Description of thrips damages was done biweekly observing the effect of the feeding activity in small berries until harvest.

Chemical and biological control: The experiment was conducted on "Niagara" table grape in a commercial vineyard, during the period of September $14^{\text {Th }}$ to October $29^{\text {Th }} 1999$. We evaluated the effects of one application of the insecticides Calypso 480SC (thiacloprid, 20mL/100L) and Mesurol (methiocarb, 100 and $150 \mathrm{~mL} / 100 \mathrm{~L}$ ), the fungus Metarhizium anisopliae (strain 1037) $\left(1 \times 10^{7}\right.$ conidia/mL) and the association of Mesurol $(100 \mathrm{~mL} / 100 \mathrm{~L})+M$. anisopliae $\left(1 \times 10^{7}\right.$ conidia $\left./ \mathrm{mL}\right)$ on thrips population during the blooming period. The control plots just received water. For the evaluation of the damage on berries, the treatments were applied three additional times: 7, 14 and 21 days after the first one. The treatments were applied with a $\mathrm{CO}_{2}$ sprayer (15lb.) with a volume of $1000 \mathrm{~L} / \mathrm{ha}$, the usual application volume in a vineyard.

Before the first application, the initial thrips infestation in the experimental plots was determined. Each treatment was represented by 12 plants with four replicates. Seven days after the first application, the number of insects was evaluated in three clusters per replicate. The evaluation was carried out by shaking the plant structures in a black plastic tray, which allowed the best visualization of the insects. The efficacy of the treatments was estimated by using the formula of Henderson \& Tilton (1955). Fourty-five days after the first application, the berries with characteristic symptoms of thrips attack were counted in four bunches per treatment. Both the number of insects and damaged berries, obtained for each replicate, were subjected to analysis of variance and the means compared by Tukey's test $(a=0.05)$. The number of insects/bunch (x) data in the first evaluation was transformed by using square root $(\mathrm{x}+5)$ before statistical analysis.

Thrips damage on "Niagara" table grape: All thrips adults sampled belonged to the genus Frankliniella. It was observed a specie complex, but Frankliniella occidentalis was the most important in the sample. The increase of thrips population coincided with the blooming period, when the adults were attracted to a large pollen amount. With the development of the grape bunches, adults and nymphs attacked the berries causing small dark points, resulting the oxidation of the cellular content. The scars become in suberized areas when the berries grow, with irregular appearance or groove (Figure 1. A and B). Those scars were observed on fruits of different ages, from berries with only $2-3 \mathrm{~mm}$ of diameter until mature bunches at harvest.
The increase of thrips attack, mainly in the beginning of the bunch development, causes large dark scars on the berries, affecting the appearance of the fruit and, probably, the quality and commercialization of the product. Also, the berries with these scars do not have a normal growth, causing deformation and, in some cases, cracking of the berries and seed prolapse (Figure 1. $\mathrm{C}$ and $\mathrm{D})$. The exposure of the fruit content allows the development of saprofitic microorganisms affecting the durability of the bunch after harvest. Adults and nymphs of this pest were also observed feeding on new leaves, causing silvery and depressed lesions in the foliar tissue. However, attack of the insect to the new growth does not seem to affect the development of leaves and the production of bunches, and is not considered a problem.

Similar damage caused by the attack of thrips have been observed it others table grapes in Europe and the USA. In studies conducted by Yokoyama (1979), for "Thompson Seedless" and "Calmeria", and by McNally et al. (1985), for "Chenin Blanc", the feeding and ovipositional activities of $F$. occidentalis did not cause differences in the size, weight and sugar content of fruits. In those cases, the damage is just considered unesthetic, interfering with the commercialization of table grapes. However, for less vigorous varieties, the attack of the thrips, as described for "Niagara", might be more significant. Considering the large area occupied with "Niagara" table grape in São Paulo, the thrips can become an important pest for this crop.

The grower did not associate the damage on the berries to the attack of the insect, so the problem was treated erroneously for some years. Since the scars become more visible with the growth of the berries and were usually confused with signs of diseases and treated with fungicides.

Chemical and biological control: Thrips infestation was observed before the first treatment application on September 14 , during the blooming period. At this time, the number of insects in each replicate (three clusters) was similar for the different treatments, with 15 thrips per replicate. Seven days after the first application, a natural reduction of the thrips population was observed in all experimental plots, probably due to the decrease of the number of flowers and pollen availability. The control plots had an average of 6.0 thrips per replicate after the first treatment application and did not differ statistically from the other treatments. However, Mesurol at 100 and $150 \mathrm{~mL} / 100 \mathrm{~L}$ and this insectcide associated with $M$. anisopliae had a control efficacy of approximately 55, 84 and $95 \%$, respectively. Calypso and the fungus $M$. anisopliae when applied separately did not reduce the thrips population with just one application. However, during the evaluation of the damaged berries, the treatments could be separated into two groups: the first represented by the control, and the second by the other treatments with an average of $9.3 \%$ of damaged berries, which corresponds to a reduction of $66 \%$ in relation to the non-treated plots (Table 1).

The low number of damaged berries in the plots treated with Calypso and the fungus did not seem to correlate with the insect control efficacy observed after the first spray. The positive effect of those two treatments related to the damage caused by the attack of the thrips, probably, due to the other three sprays 7, 14 and 21 days after the first one, which reduced the insect population. 
TABLE 1 - Mean number of thrips per three clusters, control efficacy and percentage of damaged berries on "Niagara" table grape. Limeira-SP, set./out. 1999.

\begin{tabular}{|c|c|c|c|c|}
\hline \multirow[b]{2}{*}{ Treatments } & \multicolumn{2}{|c|}{ Mean number ${ }^{1}$} & \multirow[b]{2}{*}{$\begin{array}{c}\text { Control } \\
\text { efficacy }(\%)^{2}\end{array}$} & \multirow[b]{2}{*}{$\begin{array}{c}\text { Damaged } \\
\text { berries }(\%)^{3}\end{array}$} \\
\hline & $\begin{array}{c}\text { Initial } \\
\text { population }\end{array}$ & $\begin{array}{c}\text { First } \\
\text { sample }\end{array}$ & & \\
\hline Control & $12.99 \mathrm{a}$ & $6.00 \mathrm{ab}$ & - & $27.97 \mathrm{a}$ \\
\hline M. anisopliae $\left(1 \times 10^{7} \mathrm{con} . / \mathrm{mL}\right)$ & $14.49 \mathrm{a}$ & $4.63 \mathrm{ab}$ & 0.00 & $10.07 \mathrm{~b}$ \\
\hline $\begin{array}{c}M . \text { anisopliae }+ \text { M esurol } \\
(100 \mathrm{~m} \mathrm{~L} / 100 \mathrm{~L})\end{array}$ & $12.99 \mathrm{a}$ & 0.27 & 95.50 & $7.40 \quad b$ \\
\hline Mesurol $(100 \mathrm{~mL} / 100 \mathrm{~L})$ & $17.01 \mathrm{a}$ & $3.55 \mathrm{ab}$ & 54.90 & $8.25 \mathrm{~b}$ \\
\hline Mesurol (150mL/100L) & $17.25 \mathrm{a}$ & 1.25 & 84.20 & $8.85 \mathrm{~b}$ \\
\hline Calypso $(20 \mathrm{~mL} / 100 \mathrm{~L})$ & $16.50 \mathrm{a}$ & $11.45 \mathrm{a}$ & 0.00 & $12.07 \mathrm{~b}$ \\
\hline
\end{tabular}

${ }^{1}$ number of thrips in three clusters, seven days after first spray

${ }^{2}$ calculated by Henderson\&Tilton (1955)

${ }^{3}$ after 4 spray applications


FIGURE 1 - Sequence of thrips damage on "Niagara" table grape. Limeira-SP, set./out. 1999.

A single spray of Mesurol at 150 and $100 \mathrm{~mL} / 100 \mathrm{~L}$ controlled the thrips population, as shown by the low number of insects per replicate, with 1.25 and 3.55 thrips respectively. The association of the insecticide and the fungus $M$. anisopliae eliminated the insects, resulting in less than 0.1 thrips per cluster (Table 1). The efficacy of carbamates insecticides for control of Frankliniella was also observed by Guerra-Sobrevilla (1989) with aldicarb applications during the blooming period of "Thompson Seedless". During this period, the thrips population feeding on grape increases, resulting on a great number of damaged berries (McNally et al., 1985; Moleas \& Addante, 1995).
The results obtained in the present study confirm the importance of thrips control during the blooming period and the beginning of the bunch development in reducing the number of damaged berries.

The development of resistance has been a serious problem in the control of thrips. Observations in field and some studies showed the resistance of this group of insects to different insecticides (Immaraju et al., 1992; Robb et al., 1995). There is no single solution for the resistance problem; the best focus is based on the integration of different control tactics, including the cultural, physical and biological control (Robb \& Parrella, 1995). Among the biological control agents, the fungus M. anisopliae shows a great potential for the thrips control. In laboratory conditions, the strain 1037 (Entomology Department of ESALQ/ USP) was selected and later used with success for control of $F$. occidentalis in commercial production of hydroponic lettuce in greenhouse (Lopes, 1999; Lopes et al., 2000). The association of selective chemical insectides with entomopathogenic fungi could provide a more effective control of thrips. The unique mode of action of the fungus allows management of the pesticide resistance, and the rational use of chemical insecticides can reduce the toxic residues on fruits (Alves, 1998). A reduction of $50 \mathrm{~mL}$ in the dosage of the insecticide Mesurol could also result on the prevention of resistance development by the thrips populations and in less environmental pollution. The application of $M$. anisopliae in association with the insecticide Mesurol, represents a viable strategy for the control of thrips on "Niagara" table grape.

\section{REFERENCES CITED}

ALVES, S.B. Patologia e controle microbiano: Vantagens e desvantagens. In: ALVES, S.B. (Ed.), Controle microbiano de insetos. 2.ed. Piracicaba: FEALQ, 1998. p.21-37. 
GUERRA-SOBREVILLA, L. Effectiviness of aldicarb in the control of the western flower thrips, Frankliniella occidentalis (Pergande), in table grapes in Northwwestern Mexico. Crop Protection, Kidlington, v.8, p.277-279, 1989.

HENDERSON, C.F.; TILTON, E.W. Tests with acaricides against the brown wheat mite. Journal of Economic Entomology, Leanham, v.48, p.157-161, 1955.

IMMARAJU, J.A.; PAINE, T.D.; BETHKE, J.A.; ROBB, K.L.; NEWMAN, J.P. Western flower thrips (Thysanoptera: Thripidae) resistance to insecticides in Coastal California greenhouses. Journal of Economic Entomology, Leanham, v.85, n.1, p.9-14, 1992.

LOPES, R.B. Seleção de fungos entomopatogênicos e controle de Frankliniella occidentalis (Pergande) (Thysanoptera: Thripidae). 1999. 74f. Dissertação (Mestrado em Entomologia) Escola Superior de Agricultura "Luiz de Queiroz”, Universidade de São Paulo, Piracicaba, 1999.

LOPES, R.B.; ALVES, S.B. TAMAI, M.A. Fungo Metarhizium anisopliae e o controle de Frankliniella occidentalis em alface hidropônico. Scientia Agrícola, v.57, n.2, p.239-243, 2000.

McNALLY, P.S.; FOGG, C.; FLYNN, J.; HORENSTEIN, J. Effects of thrips (Thysanoptera: Thripidae) on shoot growth and berry maturity of "Chenin Blanc" grapes. Journal of Economic Entomology, Leanham, v.78, n.1, p.69-72, 1985.
MOLEAS, T.; ADDANTE, R. Western flower thrips on table grapes in Southern Italy. In: PARKER, B.L.; SKINNER, M.; LEWIS, T. Thrips biology and management. New York: Plenum Press, 1995. p.575-578.

PALMER, J.M.; MOUND, L.A.; DU HEAUME, G.J. CIE Guide to Insects of Importance to Man - 2. Thysanoptera. London: CAB International Institute of Entomology, 1989. 74p.

RIPA, R.S.; RODRIGUES, F.A.; VARGAS, R.M. Asociacion entre trips (Thrips tabaci Lindeman y Frankliniella cestrum Moulton) durante la floracion en uva de mesa y "russet"en la cosecha. Control quimico. Agricultura Tecnica, Santiago, v.52, n.3, p.231$240,1992$.

ROBB, K.L.; NEWMAN, J.; VIRZI, J.K.; PARRELLA, M.P. Insecticide resistance in western flower thrips. In: PARKER, B.L.; SKINNER, M.; LEWIS, T. Thrips Biology and Management. New York: Plenum Press, 1995. p.341-346.

ROBB, K.L.; PARRELLA, M.P. IMP of western flower thrips. In: PARKER, B.L.; SKINNER, M.; LEWIS, T. Thrips Biology and Management. New York: Plenum Press, 1995. p.365-370.

YOKOYAMA, V.Y. Effect of thrips scars on table grape quality. Journal of the American Society Horticulturl Science, Alexandria, v.104, n.2, p.243-245, 1979. 